University of South Florida

DIGITAL COMMONS

Digital Commons @ University of

@ UNIVERSITY OF SOUTH FLORIDA

South Florida

\title{
Changing the Game: College Dance Training for Well-Being and Resilience Amidst the COVID-19 Crisis
}

Joe Bohn

University of South Florida, jbohn2@usf.edu

Stephanie Hogue

University of South Florida, renee31@usf.edu

Follow this and additional works at: https://digitalcommons.usf.edu/usf_fcrc_all

\section{Scholar Commons Citation}

Bohn, Joe and Hogue, Stephanie, "Changing the Game: College Dance Training for Well-Being and Resilience Amidst the COVID-19 Crisis" (2020). All publications. 80.

https://digitalcommons.usf.edu/usf_fcrc_all/80

This Article is brought to you for free and open access by the USF Libraries Florida COVID-19 Research Collections at Digital Commons @ University of South Florida. It has been accepted for inclusion in All publications by an authorized administrator of Digital Commons @ University of South Florida. For more information, please contact digitalcommons@usf.edu. 


\section{$1 \quad$ Assessment of Need}

In January 2020 a large-scale pandemic, caused by the novel coronavirus, SARS-CoV-2

3 (i.e., COVID-19), swept through global communities, crippling national economies, taxing

4 health systems worldwide, and massively transforming the way education was delivered

5 (Kickbusch I., et al., 2020). Across the United States, starting in February/March 2020, there was

6 an expanding sense of fear, anxiety and depression as the virus spread (Zhai, Y., \& Du, X.,

7 2020). As the severity of the pandemic was realized, community lockdowns began and social

8 distancing measures were implemented in mid-March 2020. In Florida, in particular, cases of

9 COVID-19 continued to climb into June and July 2020: according to the CDC, Florida

10 maintained some of the highest case counts in the country (Centers for Disease Control and

11 Prevention [CDC], 2020), reinforcing the continued importance of physical distancing and

12 closure of many social settings. The limited social connectedness during this time underscored

13 the need to maintain class and community connectivity. One professor at the University of South

14 Florida's (USF) College of Public Health, a prominent research university in Florida, who had

15 focused his life outside of school on dance training for three and a half years, conceived of a

16 dance training intervention to help his students and others during this continuing pandemic.

\section{Overview of the Intervention}

18 With the growing uncertainty associated with indefinite lockdowns, anxiety, fear, and

19 depression were setting in for the college students and faculty alike. One professor decided to use

20 an online conference platform to bolster mental health and well-being for students and

21 community members by hosting a virtual dance class every week. This was in response to

22 interest from students in the college and with the motivation of other experienced dance

23 instructors who were also trying to determine the best virtual tools to continue their classes. 
24 Given the circumstances surrounding the lockdown and the novel nature of this intervention,

25 particularly the professor's novice as a dance teacher, select community members were invited

26 based on personal connection with the professor.

27 Dance training was an ideal focus of the intervention as it is a movement therapy with

28 numerous physical and mental health benefits including: management of anxiety and depression,

29 improvement of self-esteem and betterment of motor skills (Ward, 2008; Murcia-Quiroga, et. al.,

30 2010). Part of the novelty of this effort lay in the fact that the professor was new to dance

31 instruction, despite being a long-time dance student. The rapid transition to dance teacher

32 required focusing on the language of dance, determining what virtual platforms were most

33 efficient and what lessons were compatible with virtual learning constraints, and adapting to

34 virtual feedback from students, often without visual cues. He asked the students and community

35 participants to focus on three core principles: timing, connection and purpose. This intervention

36 therefore provided an opportunity to maintain connectedness in a virtual setting focused through

37 a movement therapy program.

For recruitment, the free dance classes were advertised through informational flyers,

39 focusing on the no cost and no need for partner aspects of the course, circulated through email.

40 The lessons initially focused on the basics of three partnered style dances. However in Week 4,

41 following the request of a student participant, a shift was made to line dances. We quickly

42 realized that this style of dance was optimal to teach in a virtual setting because the patterns do

43 not traditionally require a partner which accommodated participants living alone or with others.

44 In the first 8-weeks of classes, teaching skills were sharpened and student feedback helped

45 determine best methods for presenting the lessons on virtual platforms. Microsoft@ Teams was

46 used as it was readily accessible to both students and other community members. 
At different points in the lesson plan development, the professor consulted with his dance

48 teacher who provided coaching to strengthen his new dance teaching skills under the crisis

49 situation. Techniques were strengthened that included video on-screen technique demonstration,

50 repetition to facilitate student learning of footwork, lesson pacing, and planning to include a

51 basic pattern followed by creative intermediate versions.

52 The final line dance lessons consisted of a collection of five different 16 to 36 count, four

53 wall patterns that were repeatedly practiced during one class to music of different speeds. These

54 classes began with easier patterns at slower speeds, progressing to faster music and more

55 complicated patterns. This structure enabled students to become comfortable with the overall

56 dance, gain confidence and bolster wellbeing. This model was utilized, following a 3-week

57 break, to develop an evaluable, 8-week, 5-session virtual line dance program. The goal of this

58 initiative was to bring together students and community members in a virtual setting during a

59 time when physical interaction was not possible, to help dampen feelings of fear, anxiety, and

60 depression, and provide students and others who participated with emotional revitalization,

61 particularly for those living in isolation, and a new movement therapy routine that builds

62 confidence, creativity and hope.

\section{Evaluation}

64 For the first 8-weeks of free classes the instructor and one graduate student exchanged

65 field notes (written within 24 hours of each lesson) on what could be improved in terms of the

66 approach. This was an unplanned action but provided a historical record of qualitative

67 assessment and evaluation of what worked well and where improvements were needed. As the

68 virtual dance class was established in a time of crisis, there was no formal class registration or

69 assessment process. Classes were not recorded so there were no audio or video recordings to 
70 reference. The instructor and graduate student conducted a manual review of field notes,

71 documented between April to June 2020, using Microsoft ${ }^{\circledR}$ Excel to catalog and code select

72 notes. This produced a thematic analysis which identified five emergent themes: video/audio-

73 technology selection; dance selection; music selection/synchronization; student and participant

74 engagement; and choreography-music synchronization. The instructor and graduate student

75 reviewed and discussed the resulting themes to assess completeness based on their independent

76 review of records made. As shown in Table 1, we also identified lessons learned and

77 opportunities for program development.

\section{Challenges and Successes}

79 Given the program's development during an ongoing crisis, there were a number of

80 successes. Participation was a win given the newness of the program; likewise, it was free to

81 participants. Participants not only came from the student body, but also included other university

82 faculty and community members from New Jersey, Ohio and Indiana, creating new social

83 connections for participants. Second, development of the line dance program curriculum was

84 created while teaching a new dance each week; this is a testament to time-management and fast-

85 paced curriculum development. Most importantly, the classes opened an opportunity for

86 participants to strengthen mental wellness and reduce anxiety given the isolation experienced

87 during a time of extreme stress adjusting to an altered life during the COVID-19 pandemic. A

88 key challenge was the distress some students were under due to their own fears for family

89 members; this affected participation rates in the program (i.e., fewer students may have been

90 motivated to participate if they did not feel they had the time or energy). Classes were held on

91 Friday or Saturday nights each week, given that social establishments were all closed. For some

92 this made the class appealing, but for others scheduling may still have been a problem. Table 1 
93 provides more insights based on themes identified from the instructor and student's field notes

94 and reflections.

INSERT TABLE 1 HERE

\section{Next Steps}

A second 8-week program followed this first program and additional field notes were

98 captured to allow for future methods analysis with appropriate CDC Healthy Days measures for

99 influence on participant wellbeing (analyses are ongoing). The select community members that

100 participated enriched the program experience for the student participants, especially under the

101 lockdown situation. Future applications of this intervention should consider additional

102 community members involvement, also at the discretion of the dance instructor/faculty member

103 and participants (i.e., encourage participants to invite family and friends). This can elicit more

104 participants to join while simultaneously keeping virtual class sizes, and hence functionality of

105 virtual programs, manageable.

\section{Implications for Practice}

107 While this program may have been simple for experienced dance instructors, it was a

108 testament to what can be created in the face of adversity. Practice implications include first the

109 opportunity to expand on the program beyond its base programming in the future. The

110 intervention provided a virtual opportunity for building social connections and improved mental

111 well-being among individuals experiencing stress (e.g., college students, faculty and community

112 members). Second, should future lockdowns ever occur due to another crisis, pandemic or

113 weather hazards, this program can serve as a model for other communities and colleges to adopt,

114 particularly if faced with future social or physical distancing protocols. Last, this program held

115 great experiential value in community engagement and service learning for students to see an 
example of how one can recognize a need and creatively devise a simple yet novel intervention

117 to help people in need.

\section{ACKNOWLEDGEMENT}

120 Special thanks to USF instructor, Teresa Anthony and USF Professor, Dr. Jason Anthony, for

121 their participation and critiques during the dance program.

\section{References}

124 Centers for Disease Control and Prevention (10 July, 2020). Coronavirus disease 2019 (COVID19): Cases in the US. Retrieved from https://www.cdc.gov/coronavirus/2019-ncov/casesupdates/cases-in-us.html

Kickbusch I, Leung GM, Bhutta ZA, Matsoso MP, Ihekweazu C, Abbasi K, et al. (2020). Covid19: how a virus is turning the world upside down. BMJ, 2020; 369:m1336.

Murcia-Quiroga, C, Kreutz, G, Clift, S, \& Bongard, S. (2010). Shall we dance? An exploration

132 Ward, S. A. (2008). Health and the Power of Dance. Journal of Physical Education, Recreation 133 \& Dance, 79(4), 33-36.

134 Zhai, Y., \& Du, X. (2020). Addressing collegiate mental health amid COVID-19 pandemic.

135 Psychiatry Research, 113003.

Table 1. Lessons Learned and Opportunities by Emergent Theme

\begin{tabular}{|l|l|l|}
\hline \multicolumn{1}{|c|}{ Emergent Theme } & \multicolumn{1}{|c|}{ Lessons Learned } & \multicolumn{1}{c|}{ Opportunities for Development } \\
\hline $\begin{array}{l}\text { Video/audio- } \\
\text { technology selection }\end{array}$ & $\bullet \begin{array}{l}\text { Need ease of use for range } \\
\text { of users }\end{array}$ & $\begin{array}{l}\text { Synchronization of instructor audio } \\
\text { and music audio in virtual setting } \\
\text { can be challenging }\end{array}$ \\
& $\begin{array}{l}\text { Selection process for } \\
\text { determining best } \\
\text { teleconferencing capability } \\
\text { required participant } \\
\text { engagement/trial and error }\end{array}$ & $\begin{array}{l}\text { Selecting best fit wireless blue-tooth } \\
\text { microphone and synchronization } \\
\text { with music audio output }\end{array}$ \\
\hline Dance selection & $\bullet \begin{array}{l}\text { Recognize speed of learning } \\
\text { for beginner dancers (focus } \\
\text { on gradation - slow, } \\
\text { medium, fast-paces) }\end{array}$ & $\begin{array}{l}\text { Build on emergent creativity to } \\
\text { broaden diversity of line dance } \\
\text { patterns }\end{array}$ \\
\hline $\begin{array}{l}\text { Focus on simpler patterns first and } \\
\text { build to more complicated patterns }\end{array}$ \\
\hline
\end{tabular}




\begin{tabular}{|c|c|c|}
\hline $\begin{array}{l}\text { Music selection- } \\
\text { synchronization }\end{array}$ & $\begin{array}{l}\text { - Increased awareness of } \\
\text { music copyright law and } \\
\text { useage rights } \\
\text { - } \begin{array}{l}\text { Matching music tempo to } \\
\text { complexity of dance patterns }\end{array} \\
\text { - } \begin{array}{l}\text { Diversifying music genres } \\
\text { used }\end{array}\end{array}$ & $\begin{array}{l}\text { Explore and advertise different } \\
\text { music genres to engage wider } \\
\text { audience } \\
\text { - Ask participant feedback on musical } \\
\text { genres }\end{array}$ \\
\hline $\begin{array}{l}\text { Student and } \\
\text { participant } \\
\text { engagement }\end{array}$ & $\begin{array}{l}\text { - Have a diverse mix of music } \\
\text { genres } \\
\text { - Empower students to help } \\
\text { plan the dance program }\end{array}$ & $\begin{array}{l}\text { - } \begin{array}{l}\text { Strengthen recruitment and } \\
\text { registration strategies to grow } \\
\text { participation }\end{array} \\
\text { - Continue to build on health and } \\
\text { wellbeing benefits for all participants }\end{array}$ \\
\hline $\begin{array}{l}\text { Choreography-music } \\
\text { synchronization }\end{array}$ & $\begin{array}{l}\text { - Create variations of each } \\
\text { dance taught for } \\
\text { intermediate lessons }\end{array}$ & $\begin{array}{l}\text { - Continue building competency in } \\
\text { understanding dance choreography } \\
\text { to music synchronization }\end{array}$ \\
\hline
\end{tabular}

